\title{
Perilaku sosial budaya masyarakat dan implikasinya pada nilai-nilai kewarganegaraan
}

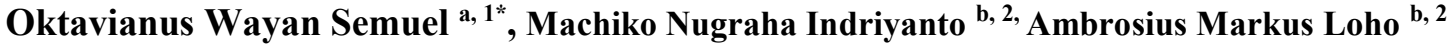 \\ ${ }^{a}$ Universitas Katolik De La Salle Manado, Fakultas Hospitality \& Pariwisata, Manado, Indonesia, Fakultas \\ Keperawatan. \\ 11 osemuel@unikadelasalle.ac.id.mindriyanto@unikadelasalle.ac.id. aloho@unikadelasalle.ac.id.
}

\begin{tabular}{ll}
\hline Informasi artikel & ABSTRAK \\
\hline Sejarah artikel: & Pariwisata adalah sektor unggulan yang saat ini mengalami perkembangan \\
Diterima: & pesat. Pariwisata adalah penting sehingga harus ditunjang oleh berbagai \\
10 Desember 2020 & hal. Maka karena hal itu penting, kita perlu mengembangkan serta \\
Disetujui: & mendayagunakan sumber dan potensi kepariwisataan di daerah setempat. \\
18 Desember 2020 & Locus penelitian ini adalah masyarakat pesisir Tanjung Amurang, maka \\
\hline Kata kunci: & peningkatan kapasitas sumber daya masyarakat di tempat inilah yang akan \\
Pariwisata & menjadi objek penelitian ini. Dan hal penting terkait ini adalah civic skills. \\
Sosial & Civic skills yang meliputi keterampilan intelektual (intellectual skills) dan \\
Budaya & keterampilan berpartisipasi (participatory skills) dalam kehidupan \\
Civics & berbangsa dan bernegara, perlu ditingkatkan, karena belum maksimal. \\
Keterampilan & Adapun metode yang akan digunakan untuk mengurai hal itu adalah \\
& metode deskriptif-kualitatif, yang mana didalamnya akan digambarkan \\
& dan diinterpretasikan objek sesuai dengan apa adanya keadaan di \\
& lapangan. Hasil dari penelitian ini akan menjadi sebuah pertimbangan \\
penting dalam hal perilaku masyarakat, terutama untuk menunjang \\
pariwisata Tanjung Amurang. Termasuk memberi rekomendasi dalam \\
peningkatan upaya untuk peningkatan civics skills masyarakat.
\end{tabular}

Keywords:

Tourism

Social

Culture

Civics

Skills

\begin{abstract}
Socio-cultural behavior of society and its implications for civic values. Tourism is a leading sector which is currently experiencing rapid development. Indonesia as a cultural superpower pays important attention to this sector. Tourism is an industry that causes rapid economic growth which certainly has an important role for Indonesia. Therefore, the tourism sector gets special attention by developing and utilizing the resources and potential of national tourism. On the other hand, civic skills are important because they are related to efforts to empower a country. As we know, civic skills include intellectual skills and participatory skills in the life of the nation and state. Intellectual skills are skills in responding to various problems of reality, including skills in terms of participation through polite behavior in social and cultural life. The coast of Tanjung Amurang as a research locus, also needs to be supported by the socio-cultural behavior of the local community. This research will describe the implications of citizenship values for the development of Tanjung Amurang tourism. The value of civics skills is one that will be an important point.
\end{abstract}

Copyright (C) 2020 (Oktavianus Wayan Semuel, dkk.). All Right Reserved

\section{Pendahuluan}

Pariwisata adalah sektor unggulan yang sementara berkembang pesat di Indonesia. Kegiatan untuk melakukan perjalanan wisata atau biasa dikenal dengan traveling telah 
menjadi gaya hidup dan kebiasaan masyarakat saat ini. Bandingkan banyaknya orang atau anak muda yang menyebut diri traveller. Sejalan dengan itu, tampilnya orang-orang sebagai traveller disinyalir didukung oleh fakta bahwa negara kita Indonesia, memiliki keindahan alam yang luar biasa. Dan fakta ini adalah penunjang utama sektor pariwisata di Indonesia. (Isdarmanto, 2017).

Pariwisata merupakan industri baru yang menyebabkan terjadinya pertumbuhan ekonomi yang cepat, serta kegiatan ini memiliki peran yang sangat penting dalam membangun Indonesia dalam hal ini yang dimaksudkan adalah sebagai penghasil devisa negara yang cukup besar. Maka dari itu sektor pariwisata mendapatkan perhatian khusus dengan mengembangkan serta mendayagunakan sumber dan potensi kepariwisataan nasional. Bentuk-bentuk pelestarian sumber daya dan lingkungan akan memberikan dampak terhadap kehidupan masyarakat lokal (Suwena \& Widiatmaja, 2017).

Di sisi lain, civic skills merupakan hal penting karena terkait dengan upaya memberdayakan sebuah negara. Sebagaimana kita ketahui, civic skills meliputi keterampilan intelektual (intellectual skills) dan keterampilan berpartisipasi (participatory skills) dalam kehidupan berbangsa dan bernegara. Contoh keterampilan intelektual adalah keterampilan dalam merespon berbagai persoalan politik, termasuk keterampilan berpartisipasi dalam berperilaku santun dalam kehidupan sosial dan budaya, terutama ketika semua orang sekitar Tanjung Amurang menjalankan hak dan kewajibannya dalam meningkatkan pariwisata.

Dari latar ini, penulis menyakini bahwa pengelolaan pariwisata berbasis budaya memang tidak lepas dari perilaku sosial masyarakat. Juga karena pariwisata memang perlu perlu ditunjang oleh segala hal, termasuk kehidupan sosial, budaya dan tentu saja semua kalangan, semua pihak. Kondisi sosial budaya setempat memang butuh orang-orang yang memiliki ketrampilan, yang mampu mengolah diri dan memberi diri untuk bisa mengambil bagian dalam pengembangan pariwisata.

Setiap individu yang memiliki ketrampilan itu, tentu harus turut mengelola sekitarnya, apalagi jika mereka tinggal di daerah tujuan wisata. Pengelolaan dengan memanfaatkan potensi pariwisata yang dimiliki setiap daerah harus mampu dikelola se-maksimal mungkin dengan tetap melestarikan segala potensi yang ada sehingga dapat menjadi daya tarik bagi wisatawan yang datang. Berkembangnya pariwisata di suatu daerah akan mendatangkan banyak manfaat bagi masyarakat, yakni secara ekonomis, sosial dan budaya. Namun, jika pengembangannya tidak dipersiapkan dan dikelola dengan baik, justru akan menimbulkan berbagai permasalahan yang menyulitkan atau bahkan merugikan masyarakat.

Provinsi Sulawesi Utara adalah salah satu daerah di Indonesia yang memiliki perhatian khusus terhadap pariwisata, karena memiliki potensi pariwisata dan daya tarik yang beragam untuk ditemukan. Sulawesi Utara berada di urutan pertama pertumbuhan pariwisata dibandingkan provinsi lain. Pertumbuhan pariwisata yang meningkat cukup tajam berhasil membawa penghargaan The Rising Star Tourist Destination 2019 untuk Provinsi Sulawesi Utara. Dari tahun 2015 hingga 2018 misalnya, tercatat kenaikan kunjungan wisatawan di Sulawesi Utara mencapai 600 persen. Hal-hal seperti ini menjadi bukti nyata bahwa di Provinsi Sulawesi Utara serius dan benar-benar ingin mengembangkan lagi potensi pariwisata di daerah ini agar dapat menjadi daya tarik bagi wisatawan lokal maupun mancanegara untuk datang berkunjung lagi dan lagi.

Saat ini pengembangan pembangunan di Kabupaten Minahasa Selatan mengusung konsep pembangunan "Water Front City". Hal ini sudah mulai terlihat dengan pembangunan secara besar-besaran antara lain perbaikan jalan Boulevard Amurang. Implementasi pembangunan jalan Boulevard Amurang ini, selain bertujuan untuk mengurangi kemacetan dalam kota, ruas jalan membentang di tepi pantai tanjung Amurang ini mulai menjadi ikon serta kawasan pengembangan pariwisata yang baru. Dalam pengembangan potensi wisata yang ada di Kabupaten Minahasa Selatan, sesungguhnya tidak kalah bersaing keindahannya 
dengan kabupaten/kota lain. (http://minselkab.go.id/3.8091.11/pages/kabupaten-minahasaselatan).

Penelitian ini akan fokus pada bagaimana nilai-nilai kewarganegaraan bisa memberi banyak pengaruh pada pengembangan pariwisata, dilihat dari perilaku sosial budaya masyarakat. Dengan uraian ini, maka kita akan mengetahui bahwa perilaku sosial bisa menjadi salah satu kunci vital dalam pengembangan pariwisata yang akhirnya akan mempengaruhi pembangunan secara keseluruhan.

\section{Metode}

Penelitian ini menggunakan metode deskriptif-kualitatif, yang menggambarkan dan menginterpretasi objek sesuai dengan apa adanya. Dengan metode deskriptif, penelitian memungkinkan untuk melakukan observasi lapangan, menguji hipotesis, mengembangkan generalisasi, dan mengembangkan teori yang memiliki validitas universal. Penggalian data ditempuh melalui wawancara dan studi pustaka untuk memperoleh informasi, termasuk melalui literatur jurnal, buku-buku dan penelitian ilmiah yang relevan untuk selanjutnya dianalisa.

\section{Hasil dan Pembahasan}

Tanjung Amurang adalah salah satu tempat favorit bagi masyarakat Minahasa Selatan, tetapi juga masyarakat Sulawesi Utara pada umumnya. Pesona pesisir pantai menjadi pembeda dalam objek-objek pariwisata di Minahasa Selatan, terutama di Amurang (Badan Pusat Statistik Minahasa Selatan, 2019). Dalam membangun Minahasa Selatan, tampak jelas bahwa masyarakat sangat setuju dengan pengembangan yang dilakukan di pesisir Tanjung Amurang ini. Kendati demikian setuju, tapi hemat penulis, terdapat berbagai problem yang vital yang perlu dikembangkan dan perlu diberi perhatian secara massif. Perilaku sosial budaya yang ada kini, pun belum menjamin hal itu bisa berkembang secara pesat. Maka dari itu, pengembangan yang dilakukan pemerintah diharapkan kedepannya masyarakat luar dapat lebih mengenal dan tertarik dengan pariwisata yang ada di daerah ini pesisir Tanjung Amurang. Masyarakat setempat tentu saja lebih menginginkan daerah mereka untuk lebih berkembang demi kepentingan bersama (Badan Pusat Statistik Minahasa Selatan, 2019).

Melampaui itu, masyarakat setempat yang amat mendukung pengembangan pariwisata di sepanjang Jalan Boulevard Tanjung Amurang ini, turut pula berpartisipasi mensosialisasikan kekhasan daerah ini. Selain itu berbagai bentuk dukungan diberikan oleh masyarakat terkait pengembangan pariwisata. Masyarakat juga menunjukkan kepedulian masyarakat terhadap pengembangan pariwisata yang ada dalam aspek sosial dapat dilihat dengan bagaimana masyarakat dapat bersikap ramah, menyambut, memberi senyum, salam serta rasa hormat kepada wisatawan lain yang berkunjung. Interaksi dari wisatawan mancanegara dengan masyarakat setempat yang secara tidak langsung menunjukkan bahwa masyarakat menyambut dengan baik kedatangan wisatawan asing ke daerah mereka.

\section{Aspek Sosial}

Dalam upaya untuk terus memamerkan pesona Tanjung Amurang ini, terdapat problem mendasar yang perlu diuraikan sebagai cara untuk menemukan jalan keluar yang solutif bagi pengembangan pariwisata. Hal itu penulis uraikan sebagai berikut: Kurangnya komunikasi antara masyarakat dengan pemerintah, terkait ditemukannya sejumlah pedagang yang akhirnya memilih berjualan di sekitar tugu "I Am Amurang" karena lokasi yang sangat berdekatan. Hal itu terjadi karena terjadi pembatasan hari operasional di pasar. Hal itu terjadi akibat kurangnya perhatian, sosialisasi maupun pemberitahuan kepada masyarakat tentang lokasi yang tidak bisa dijadikan tempat untuk berdagang (Isdarmanto, 2017). 
Selanjutnya, ternyata pola perilaku 'berkurangnya solidaritas namun meningkatnya persaingan' yang timbul akibat sikap konsumtif menjadi hambatan masyarakat yang ada sekarang terutama di pesisir Tanjung Amurang. Perkembangan mulai terjadi di Jalan Boulevard kesempatan untuk menjual makanan atau minuman bahkan penjualan hal-hal yang lain dapat timbul dengan dipicunya sikap konsumtif yang ada.

Fakta ini tentu mengetengahkan sebuah situasi bahwa di pesisir Tanjung Amurang, sebagai locus peningkatan pariwisatanya, menjadi problem utama yang perlu dicarikan solusinya. Sebagaimana perlu kita ketahui, perilaku masyarakat sebetulnya menentukan perkembangan sebuah pembangunan, termasuk pembangunan pariwisata. Hubungan antar satu individu dengan individu atau kelompok yang lain merupakan hubungan sosial yang perlu dijaga dengan sikap serta tindakan yang sesuai dengan peraturan yang berlaku dalam masyarakat. Sehingga dalam aspek sosial dapat dilihat bagaimana peranan dalam masyarakat untuk dapat megadaptasikan diri.

Tabel 1. Bentuk Dukungan dan Hambatan dalam Aspek Sosial

\begin{tabular}{|c|l|l|}
\hline No. & \multicolumn{1}{|c|}{ Dukungan } & \multicolumn{1}{|c|}{ Hambatan } \\
\hline 1 & $\begin{array}{l}\text { Perpindahan maupun penambahan } \\
\text { mata pencaharian berupa rumah } \\
\text { makan dan kafe, akomodasi, } \\
\text { freelance guide }\end{array}$ & $\begin{array}{l}\text { Kurangnya komunikasi antara } \\
\text { pemerintah dan masyarakat }\end{array}$ \\
\hline 2 & $\begin{array}{l}\text { Program edukasi sadar wisata dan } \\
\text { sapta pesona }\end{array}$ & Street Crime \\
\hline 3 & $\begin{array}{l}\text { Program Kamtibmas (Keamanan dan } \\
\text { Ketertiban Masyarakat) }\end{array}$ & Munculnya sikap konsumtif \\
\hline 4 & $\begin{array}{l}\text { Mempromosikan tempat wisata yang } \\
\text { ada }\end{array}$ & \\
\hline 5 & $\begin{array}{l}\text { Pengelolaan Pusat Informasi } \\
\text { Pariwisata }\end{array}$ & \\
\hline 6 & $\begin{array}{l}\text { Welcome -> Wisatawan lokal } \\
\text { maupun mancanegara }\end{array}$ & \\
\hline 7 & Komunitas Lokal & \\
\hline
\end{tabular}

Keterangan:Data ini berdasarkan hasil wawancara dan penemuan penulis di lapangan.

Dari tabel ini, tampak bahwa peran masyarakat untuk turut serta dalam berpartisipasi sebagai pelaku usaha wisata, menjadi hal pokok dalam peningkatan pariwisata pesisir Tanjung Amurang. Pembangunan Jalan Boulevard memberikan dampak yang cukup signifikan terhadap masyarakat setempat terlebih dampak ini ditunjukkan dengan kesadaran masyarakat dalam menata penempatan rumah yang dulunya tidak menghadap pantai tapi ketika saat sudah ada Jalan Boulevard rumah-rumah yang ada sudah menghadap pantai hal ini merupakan salah satu tujuan pemerintah Kabupaten Minahasa Selatan dalam membangun konsep kota Water Front City kedepannya. Disamping itu dampak lainnya ditunjukan dalam pengembangan pariwisata yang ada. Mulai munculnya industri-industri pariwisata dari pemerintah, swasta, bahkan masyarakatpun mengambil andil dalam pengembangan pariwisata yang terjadi di sepanjang pesisir Tanjung Amurang. (http://minselkab.go.id/3.8091.11/pages/kabupaten-minahasa-selatan).

Selain itu, peran masyarakat dalam mempromosikan objek wisata, tentu menjadi kunci utama karena sebagai masyarakat yang tinggal disepanjang pesisir Tanjung Amurang tentulah secara tidak langsung memiliki tugas penting dalam mensosialisasikan spot-spot yang menjadi daya tarik tempat ini, misalnya dengan ikon pariwisata mereka dan juga wisata 
kuliner yang ada, serta kegiatan atau event yang dilaksanakan pemerintah seperti Festival Tanjung Amurang sehingga dikenal dan diketahui oleh masyarakat luar, agar dapat mendatangkan wisatawan lokal dari kota lain maupun wisatawan mancanegara. Berbagai bentuk dukungan diberikan dari masyarakat pesisir tanjung Amurang terhadap pengembangan pariwisata yang ada disana. Baik yang dilakukan secara tidak langsung oleh masyarakat untuk membuktikan bahwa masyarakat ingin memperkenalkan pesisir tanjung amurang kepada masyarakat lain, dan yang secara langsung dilakukan masyarakat dalam menyambut siapapun wisatawan yang datang berkunjung baik wisatawan lokal maupun mancanegara.

Selanjutnya hal penting yang lain adalah interaksi yang intens antar masyarakat setempat, antar masyarakat dengan pemerintah, dan tentu saja antar masyarakat dengan para pengunjung. Hemat penulis, peran masyarakat adalah menghubungkan pihak masyarakat setempat dengan pemerintah, dan tentu saja pihak luar. Demikian juga peran aktif dari pemerintah dalam mengedukasi masyarakat setempat dalam bentuk sosialisasi-sosialisasi mengenai konsep sapta pesona serta sadar wisata sangatlah berguna dalam pengembangan pariwisata yang terjadi di pesisir Tanjung Amurang. Selain dukungan dari pemerintah masyarakat sangatlah senang terhadap kunjungan wisatawan baik wisatawan mancanegara maupun domestik. Sikap ramah tamah dan senyum merupakan bukti masyarakat menerima kunjungan wisatawan. Masyarakat setempat bersikap sangat "welcome” terhadap kunjungan wisatawan, hal ini akan sangat berpengaruh terhadap perspektif wisatawan dengan memberikan kesan yang sangat baik sehingga dapat menimbulkan keinginan bagi wisatawan untuk datang berkunjung kembali ke tempat ini.

Di satu sisi masyarakat setempat juga memiliki komunitas pemerhati pariwisata yang peduli akan kepariwisataan yang ada di sana. Kafe yaki merupakan salah satu tempat yang dijadikan Pusat Informasi Pariwisata terlebih khusus bagi wisatawan mancanegara. Hal ini murni merupakan kepedulian pemilik kafe tersebut terhadap pariwisata dengan juga menghimbau masyarakat sekitar untuk membantunya. Masyarakat sekitar membantunya secara tidak langsung dengan cara bersikap ramahserta secara langsung membantunya dalam memproduksi merchandise khas Kabupaten Minahasa Selatan yang dibuat dari batok buah kelapa.

\section{Aspek Budaya}

Dari keadaan geografis-nya, Kabupaten Minahasa Selatan merupakan pemekaran dari Kabupaten Minahasa (Bdk. http://minselkab.go.id/3.8091.11/pages/kabupaten-minahasaselatan). maka dari itu tidak heran jika budaya yang berasal dari Minahasa memiliki kesamaan dengan Minahasa Selatan. Pesisir Tanjung Amurang merupakan bagian Amurang Timur di mana sebagian besar dari etnis yang ada berasal dari etnis Minahasa yaitu suku Tontemboan $(60 \%)$, etnis Borgo (20\%) adalah etnis pencampuran dari Portugis Belanda dengan Minahasa dulunya, etnis Tionghoa (10\%) yang awalnya datang untuk berdagang namun sudah menetap, dan juga etnis-etnis lainnya (10\%).

Perbedaan etnis juga menjadi faktor terdapat perbedaan agama-agama yang di anut masyarakat setempat. Pariwisata memiliki pengaruh yang signifikan dalam masyarakat (kebudayaan) setempat, hal ini harus didukung dengan kesadaran bahwa kebudayaan merupakan sesuatu yang terjadi dalam masyarakat secara turun menurun, dan dapar berubah. Maka dari itu dalam pengembangan pariwisata harus sangat memperhatikan prosesnya dimana pariwisata menjadi pengaruh luar yang membaur dalam kehidupan masyarakat.

Dari latar belakang tersebut di atas, kita perlu menguraikan bahwa aspek budaya adalah aspek pokok dan penting untuk dijadikan penunjang pengembangan pembangunan pariwisata. Pariwisata dan budaya dapat diartikan sebagai kegiatan yang saling berhubungan dimana terjadi aktvitas pertukaran informasi seperti kesenian, makanan, tradisi, identitas, upacara dan yang lainnya. Sehingga budaya suatu daerah dapat dinikmati oleh orang lain yang datang berkunjung ke tempat tersebut. Budaya akan sangat mempengaruhi prospek dari 
kegiatan pariwisata yang dilaksanakan oleh pemerintah dan masyarakat pesisir pantai tanjung Amurang. Dalam tabel 9 merupakan hasil dari wawancara sehingga diketahui bentuk dukungan serta hambatan yang ada dalam aspek budaya.

Tabel 2. Dukungan dan Hambatan dalam Aspek Budaya

\begin{tabular}{|c|l|l|}
\hline No. & \multicolumn{1}{|c|}{ Dukungan } & \multicolumn{1}{c|}{ Hambatan } \\
\hline 1 & $\begin{array}{l}\text { Mengaplikasikan mapalus } \\
\text { dalam bentuk gotong royong }\end{array}$ & \multirow{2}{*}{ Bahasa Kasar (Makian) } \\
\hline 2 & Pemberdayaan Industri Lokal & \\
\hline 3 & $\begin{array}{l}\text { Makanan khas setempat } \\
\text { menjadi menu utama }\end{array}$ & \\
\hline 4 & $\begin{array}{l}\text { Desain dalam ruangan } \\
\text { (Interior) dihiasi dengan } \\
\text { kebudayaan khas setempat }\end{array}$ & \\
\hline 5 & $\begin{array}{l}\text { Partisipasi dalam kegiatan } \\
\text { yang dilaksanakan (Festival } \\
\text { Tanjung Amurang) }\end{array}$ \\
\hline 6 & Komunitas Budaya \\
\hline
\end{tabular}

Dari tabel 2 di atas, menunjukan bahwa berdasarkan penjelasan di atas dapat diketahui bahwa pada umumnya masyarakat setempat berasal dari etnis Toutemboan. Selain dikenal dengan sikap ramah yang merupakah ciri khas familiarnya, masyarakat yang ada di Kabupaten Minahasa Selatan juga mempraktikan budaya mapalus dalam kehidupan sehari-hari. Mapalus merupakan sistem kerja sama yang dilakukan untuk kepentingan bersama atau lebih dikenal dengan istilah gotong royong. Dalam hal ini masyarakat pesisir tanjung Amurang dalam aspek budaya dikategorikan peranannya dalam Mapalus kelompok masyarakat. Mapalus kategori ini merupakan salah satu kategori mapalus yang dapat jumpai kaitannya dengan masyarakat pesisir Tanjung Amurang dalam pengembangan pariwisata, dimana masyarakat secara sadar membentuk kelompok masyarakat yang tinggal berdekatan untuk bersama-sama untuk saling membantu, dalam hal ini dikhususkan juga dilakukan secara bergiliran untuk membersihkan lingkungan sekitar mereka.

Kegiatan gotong royong untuk membersihkan sudah dijadwalkan dan di atur oleh pemerintah setempat dengan kesadaran dari masyarakat itu sendiri. Masyarakat masih sangat familiar dengan budaya mapalus ini sejak dulu hingga sekarang dan sangat patutlah untuk dipertahankan. Hal ini lah yang menjadi salah satu faktor pendukung pelaksanaan peranan masyarakat dalam aspek budaya. Pelestarian budaya, nilai serta norma yang berada di Kabupaten Minahasa Selatan menjadi pokok peranan masyarakat nantinya dalam menghadapi pengembangan pariwisata yang ada disana.

\section{Peran Masyarakat Sebagai Penunjang Utama Pengembangan Pariwisata Pesisir Tanjung Amurang dan Implikasinya Bagi Nilai-Nilai Kewarganegaraan}

Peran masyarakat akhirnya menjadi yang terpenting, maka dari itu, penulis menemukan bahwa peran masyarakat terutama pesisir, sangat tampak dan vital terlah turut serta menjadi pelaku usaha praktis. Andreas \& Savitri menegaskan bahwa program pemberdayaan ekonomi masyarakat pesisir merupakan wujud konkrit komitmen pemerintah untuk membantu masyarakat pesisir khususnya masyarakat nelayan agar keluar dari keterpurukan ekonomi dan kemiskinan. Pemberdayaan ini memiliki tujuan untuk meningkatkan kesejahteraan 
masyarakat pesisir melalui pengembangan kegiatan pariwisata, ekonomi, kualitas sumberdaya manusia (Andreas \& Savitri, 2016).

Dengan apa yang sudah mereka perankan seperti saat ini, yakni memberdayakan industri lokal berupa kafe ataupun rumah makan dengan melestarikan nilai budaya yang ada, adalah penunjang utama perkembangan pembangunan setempat. Dari sisi perilaku, masyarakat pesisir Tanjung Amurang masih sangat mempertahankan serta melestarikan budaya yang ada karena kesadaran mereka terhadap nilai-nilai budaya yang merupakan bagian dari cara hidup masyarakat masa lampau yang diturunkan hingga saat ini. Terdapat beberapa lokasi usaha yang menerapkan pengembangan serta pelestarian budaya setempat sehingga dapat dikenal oleh wisatawan domestik maupun mancanegara.

Selain itu, peran masyarakat juga tampak lewat pembentukan komunitas budaya. Pembangunan wisata buatan berupa tugu I am Amurang, ikon tulisan wonderful minsel dan i love minsel menjadi salah satu daya tarik yang ada di sepanjang pesisir Tanjung Amurang. Hal ini dimanfaatkan oleh komunitas masyarakat setempat yaitu "Amurangers" untuk melestarikan budaya sekaligus dapat menghasilkan uang dengan cara mementaskan tarian Kabasaran di depan tugu I am Amurang. Karya kreatif ini, tentu perlu semakin digalakan. Kendati begitu, pemerintah perlu semakin menggalakkan komunitas-komunitas budaya yang ada, sehingga bisa semakin menyebar pengembangan budaya ini (Nainggolan \& Pandiangan, 2019).

Di sisi yang sama, hal penting yang perlu semakin ditingkatkan adalah interaksi sosial. Interaksi sosial dapat berlangsung apabila terpenuhi syarat-syarat (Umanailo, 2016). sebagai berikut: Pertama, kontak sosial, yaitu peristiwa terjadinya hubungan, sambungan atau sentuhan sosial (dapat disertai sentuhan jasmaniah maupun tidak) antara dua orang atau lebih. Kedua, komunikasi, yaitu proses penyampaian pesan atau informasi dari satu pihak (komunikator) ke pihak lain (komunikan) dengan menggunakan simbol-simbol. Simbol dapat berupa kata-kata, suara, gerak isyarat, benda, dan sebagainya (Oktaviyanti, 2013).

Dalam konteks pengembangan pariwisata di pesisir Tanjung Amurang, perlu juga mengedepankan sisi interaksi sosial agar hal itu bisa berkembang. Interaksi menjadi kunci dalam perilaku sosial masyarakat. Demikian, jika interaksi itu bisa berjalan baik, niscaya pariwisata di tempat tertentu akan mengalami kemajuan. Sebagaimana wawancara penulis dengan masyarakat setempat, penulis meyakini bahwa interaksi wisatawan dan masyarakat lokal di suatu destinasi wisata merupakan kunci. Pesisir pantai/tanjung Amurang adalah kawasan dengan prospek pariwisata yang memadai.

Peran masyarakat dalam hal peran dalam budaya, pembentukan komunitas budaya, serta juga hal penting lain yakni interaksi sosial, akan sangat penting ketika disinergikan dengan nilai-nilai kewarganegaraan-nilai-nilai bewawasan kebangsaan. Terkait hal itu, Wyas Putra menjelaskan dalam Pariwisata Berwawasan Kebangsaan (Putra, 2016), bahwa pasal 2 UU Kepariwisataan mengatur tentang azas penyelenggaraan pariwisata dan Pasal 4-nya mengatur tentang tujuan penyelenggaraan pariwisata. Pasal 2 menentukan bahwa kepariwisataan diselenggarakan berdasarkan asas, antara lain: manfaat, kekeluargaan, adil dan merata, keseimbangan, kesetaraan; dan kesatuan, yang merupakan penjabaran dari kesadaran diri Bangsa Indonesia sebagai satu kesatuan sosial yang terbangun dari berbagai entitas sosial yang lebih kecil dan beragam, yang berasal dari etnis dan kultur yang berbeda, yang perlu senantiasa diingatkan terhadap kesatuan kebangsaan sebagai wadah hidup dalam tata pergaulan masyarakat bangsa-bangsa yang lebih besar.

Kemudian, pasal 4 UU Kepariwisataan menentukan bahwa tujuan penyelenggaraan kepariwisataan adalah: meningkatkan kesejahteraan rakyat; menghapus kemiskinan; mengatasi pengangguran; melestarikan alam, lingkungan, dan sumber daya; memajukan kebudayaan; mengangkat citra bangsa; memupuk rasa cinta tanah air; memperkukuh jati diri dan kesatuan bangsa; dan mempererat persahabatan antarbangsa, yang juga merupakan 
penjabaran dari kesadaran diri Bangsa Indonesia sebagai satu kesatuan sosial yang tersusun atas berbagai entitas sosial yang beragam yang perlu diberi pengalam hidup sebagai satukesatuan sosial dalam bentuk kesetaraan, keadilan, dan kemanfaatan, untuk memelihara rasa senasib dan sepenanggungan, serta rasa percaya terhadap kesatuan sosial yang mewadahinya.

Dari dasar hukum ini, jelaslah bahwa wawasan kebangsaan menjadi bingkai utama dalam pengembangan pariwisata. Selain itu, civics skills sebagai ketrampilan sebagai seorang warganegara, tentu terkait erat dengan wawasan kebangsaan setiap individu. Demikialah kita perlu memahami bahwa pembangunan pariwisata berbasis budaya, harus pula membangkitkan kesadaran kebangsaan (kesatuan sosialnya) akan keberadaan bentang alam sebagai aset budaya yang tidak hanya berhenti pada fungsi penanda identitas, melainkan sebagai sumber daya ekonomi yang secara sikluistis menentukan keberlanjutan hidup mereka.

Dengan memanfaatkan kesadaran kesatuan (sosial) sebagai cara untuk memelihara lingkungan hidup sebagai aset kesatuan adalah metode klasik yang diaktifkan kembali oleh beberapa bangsa. Mereka tidak berpijak pada teori-teori baru untuk menggerakkan visi dan misi itu, melainkan hanya mencontoh saja dari tata cara kehidupan kebudayaan di Indonesia, seperti misalnya Bali, yang oleh entitasnya tidak disadari sebagai sumber inspirasi (Putra, 2016).

\section{Simpulan}

Pembangunan sebuah pariwisata akhirnya harus ditunjang oleh perilaku sosial budaya, interaksi sosial antar anggota masyarakat dan pemerintah, termasuk harus berpijak pada wawasan kebangsaan dengan adanya civics skills. Kendati itu itu akan mempengaruhi kehidupan ekonomi, hal itu harus bersinergi secara tuntas dan berkesimbungan karena hal itu penting untuk kemajuan sebuah pembanguna pariwisata. Kunci utama adalah perilaku perlu terus dipertahankan juga karena perilaku menjadi kunci dalam setiap komunikasi yang akan dibangun. Dari data yang diperoleh, peran masyarakat harus semakin ditingkatkan juga karena upaya untuk memberdayakan masyarakat, telah menjadi prioritas pemerintah. Peran masyarakat dalam mempromosikan objek wisata, adalah kunci utama karena sebagai masyarakat yang tinggal di sepanjang pesisir Tanjung Amurang memiliki tugas penting untuk mensosialisasikan spot-spot yang menjadi daya tarik tempat ini. Itulah wujud dukungan masyarakat pesisir Tanjung Amurang terhadap pengembangan pariwisata yang ada di sana. Demikian juga interaksi yang intens antar masyarakat setempat, antar masyarakat dengan pemerintah, dan tentu saja antar masyarakat dengan para pengunjung, perlu semakin ditingkatkan. Dengan demikian, peran masyarakat adalah menghubungkan pihak masyarakat setempat dengan pemerintah, dan tentu saja pihak luar.

\section{Daftar Pustaka}

Andreas, \& Savitri, E. (2016). Peranan Pemberdayaan Ekonomi Masyarakat Pesisir dan Modal Sosial. NN.

Badan Pusat Statistik Minahasa Selatan. (2019). No Title. BPS Kab. Minahasa.

Isdarmanto, I. (2017). Dasar-Dasar Kepariwisataan dan Pengelolaan Destinasi Wisata. Gebang Media Aksara.

Nainggolan, N., \& Pandiangan, D. (2019). Pemberdayaan Kaum Bapa Masyarakat Pesisir Amurang Lopana Satu Untuk Mengembangkan Wisata Pantai dengan Pendekatan Holistik. VIVABIO: Jurnal Pengabdian Multidisiplin, 1(2).

Oktaviyanti, S. S. (2013). Dampak sosial budaya interaksi wisatawan dengan masyarakat lokal di Kawasan Sosrowijayan. Jurnal Nasional Pariwisata, 5(3), 201-208.

Putra, I. B. W. (2016). Pariwisata Berwawasan Kebangsaan: Suatu Analisis Berdasarkan Teori Hukum Dengan Orientasi Kebijakan. Konggres Pancasila VIII Balai Senat 
Universitas Gajah Mada Yogyakarta.

Suwena, \& Widiatmaja. (2017). Pengantar Ilmu Pariwisata. Pustaka Larasan.

Umanailo, M. C. B. (2016). Ilmu sosial budaya dasar. FAM Publishing.

http://minselkab.go.id/3.8091.11/pages/kabupaten-minahasa-selatan.

http://minselkab.go.id/3.8091.11/pages/kabupaten-minahasa-selatan. 